\title{
PENGARUH MINAT BELAJAR SISWA TERHADAP HASIL BELAJAR MATA PELAJARAN MATEMATIKA
}

\author{
Muhammad Agil Nugroho $^{a}$, Tatang Muhajang ${ }^{\left.a^{*}\right)}$, Sandi Budiana ${ }^{a)}$ \\ ${ }^{a)}$ Universitas Pakuan, Bogor, Indonesia \\ *) e-mail korespondensi : tatang.muhajang@unpak.ac.id
}

\begin{abstract}
Abstrak. Tujuan penelitian ini adalah untuk mengetahui pengaruh minat belajar terhadap hasil belajar siswa. Penelitian ini merupakan penelitian kuantitatif dengan metode studi kausal pada minat belajar sebagai variabel bebas dan hasil belajar sebagai variabel terikat. Objek penelitian ini adalah kelas VA dan VB Sekolah Dasar Negeri Kopo 01 Kecamatan Cisarua Kabupaten Bogor Semester Ganjil Tahun Pelajaran 2019/2020 berjumlah 98 dengan sampel sebanyak 50 responden. Data penelitian ini diperoleh dengan menggunakan kuisioner skala likert untuk variabel minat belajar dan menggunakan tes soal untuk variabel hasil belajar. Hasil penelitian menunjukkan bahwa terdapat pengaruh positif dan signifikan antara minat belajar terhadap hasil belajar. Hal ini berdasarkan analisis statistik yang menghasilkan koefisien determinasi $\left(r_{x y}\right)$ sebesar 0,369 dan dalam pola permasalahannya menjadi $\hat{Y}$ $=-17,14+(0,75 x)$ yang berarti tingkat pengaruh tergolong kuat dan diperoleh $t_{\text {hitung }}$ sebesar 33,28 lebih besar dari $t_{\text {tabel }}$ dengan taraf nyata nyata 0,05 sebesar 4,04 yang berarti signifikan. Berdasarkan hasil penelitian tersebut, dapat disimpulkan bahwa terdapat pengaruh yang positif dan signifikan antara minat belajar terhadap hasil belajar siswa.
\end{abstract}

Kata Kunci: minat belajar; hasil belajar

\section{INFLUENCE OF STUDENT LEARNING INTEREST IN RESULTS OF MATHEMATICS LEARNING OUTCOMES}

Abstract. The purpose of this study was to determine the effect of interest in learning on student learning outcomes. This research is a quantitative study with a causal study method on learning interest as an independent variable and learning outcomes as a dependent variable. The object of this research is the VA class and VB Kopo 01 Public Elementary School, Cisarua District, Bogor Regency Odd Semester Academic Year 2019/2020 totaling 98 with a sample of 50 respondents. The data of this study were obtained by using a Likert scale questionnaire for learning interest variables and using test questions for learning outcome variables. The results showed that there was a positive and significant influence between learning interests on learning outcomes. This is based on statistical analysis that produces a coefficient of determination (rxy) of 0.369 and in the pattern of the problem becomes $\hat{Y}=-17.14+(0.75 x)$ which means the level of influence is classified as strong and is obtained tcount of 33.28 greater than ttable with a level significant 0.05 of 4.04, which means significant. Based on these results, it can be concluded that there is a positive and significant influence between learning interests on student learning outcomes.

Keywords: interest in learning; learning outcomes.

\section{PENDAHULUAN}

Pembelajaran matematika merupakan bagian dari program pendidikan yang diajarkan dari jenjang Sekolah Dasar hingga Perguruan Tinggi. Dalam matematika, program pendidikan yang diberikan berupa pengetahuan eksak dan pasti, untuk melatih kemampuan bernalar dan menimbulkan displin dalam pemikiran. Matematika merupakan pelajaran pokok yang diajarkan di Sekolah dasar, melalui pembelajaran matematika diharapkan penalaran dan logika siswa terlatih dan berguna dalam kehidupan sehari hari. Berhasil atau tidaknya proses belajar mengajar matematika tergantung dari dalam diri siswa tersebut. Ironisnya matematika termasuk pelajaran yang tidak disukai serta menjadi momok yang menakutkan bagi siswa, siswa takut untuk belajar matematika, dan banyak yang mengeluhkan kenapa harus belajar matematika, bagi mereka matematika adalah pelajaran yang harus dihindari. Padahal pelajaran matematika sangat penting untuk masa depan bangsa.

Hal ini menyebabkan hasil belajar matematika di indonesia masih sangat rendah. Fakta tersebut selaras dengan berbagai penelitian yang telah dilaksanakan. Seperti survei rutin Programme for International Student Assessment (PISA) yang dilakukan oleh Organisation for Economic Cooperation and Development (OECD) pada tahun 2015, dalam survei ini Indonesia hanya menempati peringkat 63 dari 65 negara [1]. Bagi bangsa sebesar Indonesia hasil ini jelas masih jauh dari kata memuaskan.

Dewasa ini minat siswa dalam pelaksanaan pembelajaran matematika masih sangat kurang, kurangnya minat belajar matematika menyebabkan kemampuan siswa dalam bidang matematika terhambat. Pada mata pelajaran matematika minat dapat memiliki peranan yang sangat penting. Jika siswa memiliki minat belajar yang tinggi dalam pembelajaran matematika, siswa akan mampu belajar matematika dengan baik dan dapat melatih siswa untuk berpikir secara kritis, logis, cermat dan kreatif, sehingga menjadikan siswa mendapat hasil belajar yang baik dalam pelajaran matematika.

Pembelajaran yang terjadi pada siswa merupakan hal penting. Kegiatan belajar akan menghasilkan sebuah kemampuan yang akan di capai oleh setiap siswa. Menurut 
Gagne dalam Purwanto [2]. hasil belajar adalah terbentuknya konsep, yaitu kategori yang kita berikan pada stimulus yang ada di lingkungan, yang menyediakan skema yang terorganisasi untuk mengasimilisasi stimulus-stimulus baru dan menentukan hubungan di dalam dan di antara kategorikategori. Teori tersebut dipertegas Hamalik dalam Jihad dan Haris [3] menambahkan bahwa hasil belajar adalah pola pola perbuatan, nilai-nilai, pengertian-pengertian dan sikapsikap, serta apersepsi dan abilitas.

Ada banyak faktor yang dapat mempengaruhi kinerja kita saat belajar, faktor-faktor ini secara langsung akan mempengaruhi hasil belajar yang kita dapat. Parwati, Suryawan \& Apsari [4] mengatakan bahwa faktor yang mempengaruhi hasil belajar dapat dijabarkan sebagai berikut: Faktor Internal terdiri dari Faktor Fisiologis, berkaitan dengan kondisi fisik seorang individu. Faktor Psikologis faktor - faktor psikologis adalah keadaan psikologis seseorang yang dapat mempengaruhi proses belajar. Faktor Kelelahan, dapat dibedakan menjadi dua macam, yaitu kelelahan jasmani dan rohani (psikis)..

Selain karakteristik peserta didik atau faktor-fakor eksogen, faktor-faktor ekstern juga dapat mempengaruhi proses belajar peserta didik. Faktor ekstern tersebut antara lain: Faktor Keluarga siswa yang belajar akan menerima pengaruh dari keluarga berupa cara orang tua mendidik, relasi antara anggota keluarga, suasana rumah tangga, dan keadaan ekonomi keluarga. Faktor Sekolah, yang mempengaruhi hasil belajar mencakup metode mengajar, kurikulum, relasi guru dan siswa, relasi siswa dengan siswa, disiplin sekolah. Faktor Masyarakat, masyarakat merupakan faktor ekstern yang juga berpengaruh terhadap belajar peserta didik. Pengaruh itu terjadi karena keberadaan siswa dalam masyarakat. Pengaruh tersebut diantaranya yaitu: kegiatan siswa dalam masyarakat, media masa, teman bergaul. Pemahaman konsep dan Keterampilan Proses sains meningkat setelah siswa mengalami proses pembelajaran tugas kelompok [5].

Hasil belajar sendiri memiliki berbagai macam jenis, seperti yang diungkapkan oleh dalam Parwati, Suryawan \& Apsari [4] membagi lima jenis hasil belajar dalam beberapa kategori diantaranya :

Informasi Verbal, kemampuan mengungkapkan pengetahuan dalam bentuk bahasa, baik lisan maupun tulisan. Kemampuan secara spesifik terhadap rangsangan spesifik, kemampuan tersebut tidak memerlukan manipulasi simbol, pemecahan masalah maupun penerapan aturan. Keterampilan Intelektual, kemampuan mempresentasikan konsep dan ambang. Keterampilan intelektual terdiri dari kemampuan mengategorisasi, kemampuan analisis-sintesis fakta-konsep dan mengembangkan prinsip-prinsip keilmuan. Keterampilan intelektual merupakan kemampuan melakukan aktivitas kognitif yang bersifat khas. Strategi Kognitif, kecakapan menyalurkan dan mengarahkan aktivitas kognitifnya sendiri, kemampuan ini meliputi penggunaan konsep dan kaidah dalam memecahkan masalah. Keterampilan Motorik, kemampuan melakukan serangkaian gerak jasmani dalam urusan dan koordinasi. Sikap, kemampuan menerima atau menolak objek berdasarkan penilaian terhadap objek tersebut. Sikap berupa kemampuan internalisasi dan eksternalisasi nilai-nilai. Sikap merupakan kemampuan menjadikan nilai-nilai sebagai standar perilaku.

Penilaian hasil belajar berguna untuk mengetahui kemampuan peserta didik. Menurut Sudjana [6] tujuan maupun manfaat dari penilaian terhadap hasil belajar, yakni: 1) Mendeskripsikan kecakapan belajar siswa sehingga dapat diketahui kelebihan dan kekurangannya dalam berbagai bidang studi atau meta pelajaran yang ditempuhnya. Dengan pendeskripsian kecakapan tersebut dapat diketahui pula posisi kemampuan siswa dibandingkan dengan siswa lainnya. 2) Mengetahui keberhasilan proses pendidikan dan pengajaran di sekolah, yakni seberapa jauh keefektifannya dalam mengubah tingkah laku siswa ke arah tujuan pendidikan yang diharapkan. 3) Menentukan tindak lanjut hasil penilaian, yakni melakukan perbaikan dan penyempurnaan dalam hal program pendidikan dan pengajaran serta sistem pelaksanaannya. 4) Memberikan pertanggungjawaban (accountability) dari pihak sekolah kepada pihak-pihak yang berkepentingan.

Sampai saat ini definisi matematika masih berbeda beda dan belum mencapai kesepakatan di antara matematikawan, mereka saling berbeda dalam mendefinisikan matematika. Ruseffendi dalam Heruman [7] berpendapat bahwa Matematika adalah bahasa simbol, ilmu deduktif yang tidak menerima pembuktian secara induktif, ilmu tentang pola keberaturan, dan struktur yang terorganisasi, mulai dari unsur yang tidak definisikan ke unsur yang di definisikan, ke aksioma atau postulat, dan akhirnya ke dalil.

Berdasarkan teori di atas dapat disintesiskan bahwa hasil belajar matematika merupakan pencapaian, penguasaan, perubahan tingkah laku dan kemampuan peserta didik setelah melalui pembelajaran, mendapatkan materi tertentu dan pengalaman. Diukur melalui indikator dan evaluasi Yang meliputi aspek kognitif, afektif dan psikimotor. Dan di pengaruhi oleh beberapa faktor diantaranya faktor internal yang berarti dalam diri siswa terebut dan faktor eksternal yang berasal dari lingkungan di sekitarnya. Serta bertujuan untuk memberikan informasi tentang pembelajaran.

Minat memiliki peranan penting dalam kegiatan belajar, minat sendiri menurut Slameto [8] dan Parwati, Suryawan \& Apsari [4] berpendapat sama bahwa minat merupakan berarti keenderungan dan kegairahan tingkat tinggi atau keinginan yang besar terhadap sesuatu. Sejalan dengan itu Djamarah [9] berpendapat bahwa minat adalah suatu rasa lebih suka dan rasa keterikatan pada suatu hal atau aktivitas, tanpa ada yang menyuruh. Minat pada dasarnya adalah penerimaan akan suatu hubungan antara diri sendiri dengan sesuatu diluar diri. Jadi minat dapat diekspresikan melalui pernyataan yang menunjukkan bahwa siswa lebih menyukai suatu hal daripada hal lainnya, dapat pula dimanifestasikan melalui partisipasi dalam suatu aktivitas.

Ciri - ciri minat belajar dapat dilihat dari keinginan yang kuat untuk menaikan kualitas dirinya. Elizabeth Hurlock dalam Susanto [10] menyebutkan ada tujuh ciri minat belajar sebagai berikut: 1) Minat tumbuh bersamaan dengan perkembangan fisik dan mental. Minat disemua 
bidang berubah selama terjadi perubahan fisik dan mental, misalnya perubahan minat dalam hubungannya dengan perubahan usia. 2) Minat tergantung pada kegiatan belajar. Kesiapan belajar merupakan salah satu penyebab meningkatnya minat seseorang. 3) Minat tergantung pada kesempatan belajar. Kesempatan belajar merupakan faktor yang sangat berharga, sebab tidak semua oran dapat menikmatinya. 4) Perkembangan minat mungkin terbatas. Keterbatasan ini mungkin dikarenakan keadaan fisik yang sudah tidak memungkinkan. 5) Minat dipengaruhi oleh budaya. Budaya sangat memengaruhi sebab jika budaya sudah luntur mungkin minat juga ikut luntur. 6) Minat berbobot emosional. Minat berhubungan dengan perasaan, maksudnya bila suatu objek dihayati sebagai sesuatu yang sangat berharga, maka akan timbul perasaan senang yang akhirnya dapat diminati. 7) Minat berbobot egoisentris. Artinya jika seseorang senang terhadap sesuatu, maka akan timbul hasrat untuk memilikinya.

Dalam minat belajar seorang siswa, memiliki faktorfaktor yang mempengaruhi minat belajar yang berbeda-beda, Seperti yang dijelaskan oleh Jahja [11] minat memiliki dua faktor, yaitu kebutuhan fisik, sosial dan egoistis yang dimiliki oleh seseorang serta pengalaman yang ia alami. Pengalaman merupakan suatu dukungan dari lingkungan. Pengalaman akan diperoleh ketika siswa mengalami interaksi dengan lingkungan baik itu secara belajar maupun latihan. Lalu Taufani [12] dan Mashudi [13] berpendapat sama bahwa ada tiga faktor yang mendasari timbulnya minat adalah : 1) Faktor dorongan dalam, dorongan dari individu itu sendiri, sehingga timbul minat untuk melakukan aktivitas atau tindakan tertentu untuk memenuhinya. Misalnya, dorongan makan, menimbulkan minat untuk mencari makanan. 2) Faktor motivasi sosial, faktor ini faktor ini merupakan faktor untuk melakukan suatu aktivitas agar dapat diterima dan diakui lingkungannya. 3) Faktor emosional, minat erat hubungannya dengan emosi karena faktor ini selalu menyertai seseorang dalam berhubungan dengan obyek minatnya.

Minat belajar memiliki beberapa indikator, Menurut Slameto [8] beberapa indikator minat belajar yaitu:.

1) Perasaan Senang, apabila seorang siswa memiliki perasaan senang terhadap pelajaran tertentu maka tidak akan ada rasa terpaksa untuk belajar. Contohnya yaitu senang mengikuti pelajaran, tidak ada perasaan bosan, dan hadir saat pelajaran. 2) Keterlibatan Siswa, ketertarikan seseorang akan obyek yang mengakibatkan orang tersebut senang dan tertarik untuk melakukan atau mengerjakan kegiatan dari obyek tersebut. Contoh: aktif dalam diskusi, aktif bertanya, dan aktif menjawab pertanyaan dari guru. 3) Ketertarikan Berhubungan dengan daya dorong siswa terhadap ketertarikan pada sesuatu benda, orang, kegiatan atau bias berupa pengalaman afektif yang dirangsang oleh kegiatan itu sendiri. Contoh: antusias dalam mengikuti pelajaran, tidak menunda tugas dari guru. 4) Perhatian Siswa, minat dan perhatian merupakan dua hal yang dianggap sama dalam penggunaan sehari-hari, perhatian siswa merupakan konsentrasi siswa terhadap pengamatan dan pengertian, dengan mengesampingkan yang lain. Siswa memiliki minat pada obyek tertentu maka dengan sendirinya akan memperhatikan obyek tersebut. Contoh: mendengarkan penjelasan guru dan mencatat materi.

Merujuk pada pendapat para ahli di atas dapat disintesiskan bahwa minat belajar adalah ketertarikan individu dalam melakukan suatu pembelajaran dengan perasaan senang tanpa adanya paksaan yang menyebabkan perubahan pengetahuan, tingkah laku dan keterampilan. Serta memiliki ciri-ciri yaitu cenderung pada dasar rasa suka dan kebanggaan serta kepuasan akan yang diminati

\section{METODE PENELITIAN}

Penelitian dilaksanakan dengan pendekatan kausal melalui rancangan penelitian sebagai berikut:

Penelitian kausal ini dilaksanakan pada siswa kelas VA dan VB di Sekolah Dasar Negeri Kopo 01 Kecamatan Cisarua Kabupaten Bogor. Waktu penelitian dilaksanakan pada bulan Oktober 2019

Populasi dalam penelitian ini adalah seluruh siswa kelas V Sekolah Dasar Negeri Kopo 01 semester Ganjil Tahun Pelajaran 2019/2020 yang berjumlah 98 orang siswa. Pengambilan sampel penelitian menggunakan rumus Taro Yamane yang menghasilkan sebanyak 50 siswa sebagai sampel penelitian. Sampel tersebut terdiri dari 25 orang siswa kelas V-A dan 25 orang siswa V-B yang dipilih secara acak.

Penelitian ini terdiri dari dua variabel yaitu minat belajar sebagai variabel bebas (X) dan hasil belajar matematika sebagai variabel terikat (Y). Teknik pengumpulan data penelitian ini menggunakan metode penyebaran angket yang menggunakan skala Likert

Merujuk pada Supardi [14] untuk instrumen hasil belajar menggunakan rumus Koefisien Korelasi Biserial dan rumus $K R-20$ untuk uji validitas dan realibilitas sedangkan untuk instrumen minat baca penulis menggunakan rumus Pearson Product Moment dan rumus Alfa Cronbach. Data yang sudah terkumpul lalu melalui tahap uji prasyarat analisis yang terdiri dari uji normalitas, uji homogenitas, uji regresi linier sederhana dan uji linearitas regresi sebelum akhirnya dilakukan uji hipotesis untuk mengetahui besaran koefisien determinasinya.

\section{HASIL DAN PEMBAHASAN}

Deskripsi data penelitian dikelompokkan menjadi dua bagian yang terdiri dari data variabel terikat yaitu variabel Hasil Belajar Matematika (Y) dan data variabel bebas yaitu variabel Kebiasaan Belajar Siswa (X) yang dideskripsikan dalam bentuk deskripsi statistik.

Untuk memperjelas pengaruh variabel Minat Belajar Siswa (X) terhadap variabel Hasil Belajar Matematika (Y) yang berdasarkan uji signifikansi dan dinyatakan dalam bentuk persamaan regresi yaitu $\hat{Y}=a+b x$.

Berdasarkan hasil perhitungan, diperoleh konstanta a $=-17,14$ dan koefisien arah $\mathrm{b}=0,75$. Dengan demikian terdapat pengaruh minat belajar siswa terhadap hasil belajar 
matematika dalam bentuk persamaan regresi, yang kemudian di gambarkan pada diagram pencar di bawah ini :

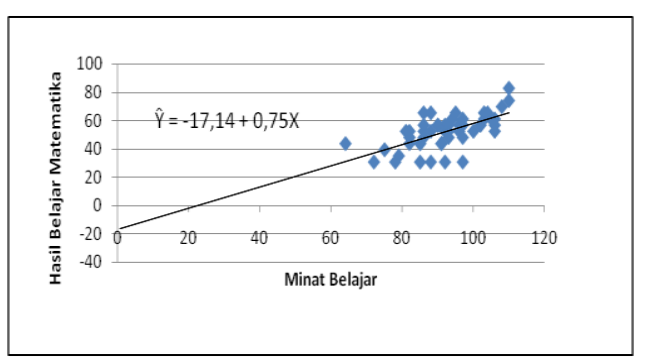

Gambar 3. Diagram Pencar Pengaruh Minat Belajar Siswa (X) Dengan Hasil Belajar Matematika (Y)

Berdasarkan perhitungan koefisien determinasi $\mathrm{r}^{2}$ antara minat belajar siswa (X) dengan hasil belajar matematika $(\mathrm{Y})$ adalah $\mathrm{r}^{2}=0,4083$ dengan koefisien determinasi $40,83 \%$. Hal ini bahwa minat belajar memberi kontribusi langsung sebesar $40,83 \%$ terhadap hasil belajar matematika, sedangkan $59,17 \%$ hasil belajar matematika dipengaruhi oleh faktor-faktor lain.

Pengujian hipotesis "Terdapat pengaruh positif minat belajar siswa terhadap hasil belajar matematika" menggunakan uji signifikansi koefisien korelasi dengan uji t pada taraf nyata terbesar $5 \%$ atau 0,05 jika $t_{\text {hitung }}>t_{\text {tabel }}$ maka koefisien determinasi dinyatakan signifikan. Berdasarkan hasil perhitungan diperoleh $\mathrm{t}_{\text {hitung }}=5,77$ dengan $\mathrm{t}_{\text {tabel }}(a=$ $0,05)=2,010$. Dengan demikian $t_{\text {hitung }}>t_{\text {tabel }}=5,77>2,010$ yang artinya $\mathrm{H}_{\mathrm{o}}$ ditolak atau tidak terdapat pengaruh minat belajar siswa $(\mathrm{X})$ terhadap hasil belajar matematika $(\mathrm{Y})$ dan $\mathrm{H}_{\alpha}$ diterima atau terdapat pengaruh minat belajar siswa (X) terhadap hasil belajar matematika (Y).

Berdasarkan hasil perhitungan kurva di atas apabila $\mathrm{t}_{\text {hitung }}$ terletak diantara $-2,010$ dan 2,010 maka $\mathrm{H}_{0}$ diterima, tetapi apabila $t_{\text {hitung }}$ tidak terletak antara $-2,010$ dan 2,010 maka $\mathrm{H}_{\mathrm{a}}$ diterima. Oleh karena didapat $\mathrm{t}_{\text {hitung }} 5,77$ dan tidak terletak diantara $-2,010$ dan 2,010 maka hasil penelitian adalah $\mathrm{H}_{0}$ ditolak dan $\mathrm{H}_{\mathrm{a}}$ diterima. Dengan demikian dapat disimpulkan bahwa terdapat pengaruh positif dan signifikan diantara minat belajar siswa terhadap hasil belajar matematika.

Pembahasan Berdasarkan hasil analisis data pengujian hipotesis diketahui bahwa terdapat pengaruh yang positif dan signifikan dari minat belajar terhadap hasil belajar mata pelajaran matematika. Dengan kata lain hipotesis penelitian diterima.

Pengaruh dari minat belajar siswa terhadap hasil belajar mata pelajaran matematika secara statistik ditunjukkan dengan hasil uji signifikansi dan regresi dengan persamaan regresi $\hat{Y}=-17,14+0,75 x$. Hal ini berarti bahwa setiap kenaikan satu unit variabel minat belajar akan menyebabkan peningkatan pada hasil belajar matematika sebesar 0,75 unit.

Kekuatan pengaruh dari minat belajar terhadap hasil belajar ditunjukkan dengan koefisien jalur sebesar 0,639. Harga koefisien tersebut menunjukkan bahwa terdapat pengaruh yang kuat dari variabel minat belajar siswa terhadap hasil belajar matematika. Selain itu dari hasil perhitungan uji signifikansi koefisien jalur diperoleh data $t_{\text {hitung }}>t_{\text {tabel }(\alpha=0,05)}=5,77>2,010$. Ini menunjukan bahwa terdapat pengaruh positif dan signifikan yang diberikan oleh minat belajar terhadap hasil belajar matematika.

Besarnya konstribusi pengaruh minat belajar siswa terhadap hasil belajar matematika ditunjukkan oleh koefisien determinasi sebesar 40,83\%. Hal ini menandakan kenaikan atau penurunan hasil belajar tema pahlawanku dipengaruhi oleh minat belajar siswa sebesar $40,83 \%$, sedangkan sisanya $59,17 \%$ dipengaruhi oleh faktor-faktor lainnya.

Hasil perhitungan tersebut didukung oleh teori yang dikemukakan oleh Dimyati dan Mudjiono [15] yang berpendapat bahwa siswalah yang menentukan terjadi atau tidak terjadinya belajar. Untuk bertindak siswa menghadapi masalah-masalah secara intern. Faktor intern yang dialami dan dihayati oleh siswa yang berpengaruh pada proses belajar sebagai berikut : 1) Sikap terhadap belajar, 2) Motivasi belajar, 3) Konsentrasi belajar, 4) Mengolah bahan ajar, 5) Menyimpan perolehan hasil belajar, 6) Menggali hasil belajar yang tersimpan, 7) Kemampuan berprestasi atau unjuk hasil belajar, 8) Rasa percaya diri siswa, 9) Intelegensi dan keberhasilan belajar, 10) Kebiasaan belajar, 11) Citacita siswa.

Berdasarkan uraian tersebut terlihat bahwa akan sulit bagi siswa untuk mengolah bahan ajar dan menggali hasil belajar yang tersimpan apabila siswa tidak memiliki minat belajar yang tinggi karena kedua kegiatan tersebut mengharuskan siswa untuk banyak belajar yang nantinya akan mempengaruhi hasil belajar. Dengan kata lain tingkat minat belajar secara langsung akan mempengaruhi hasil belajar siswa.

Selain teori di atas hasil pengolahan data dan hipotesis dapat pula dibandingkan dengan penelitian relevan yang telah ada. Contoh pertama adalah penelitian yang dilakukan oleh Astri [16]. Dari hasil perhitungan, sumbangan relatif pengaruh minat belajar terhadap hasil belajar mata pelajaran matematika adalah sebesar $25,8 \%$.

Adapula penelitian relevan lain yang telah dilaksanakan oleh oleh Ninu Septiani [17] Analisis data menunjukkan bahwa pengaruh minat belajar dan motivasi belajar terhadap hasil belajar adalah sebesar 9,6\%.

Berdasarkan uraian dua penelitian relevan dibandingkan dengan penelitian ini, terlihat tidak ada perbedaan mendasar dalam metodologi penelitian dan juga cara pengolahan data, perbedaan hanya terdapat di dalam penelitian dari Astri [16] dimana pengambilan sampelnya menggunakan teknik sampel populasi.Justru terlihat sekali kesamaan dari hasil ketiga penelitian tersebut dimana minat belajar memberikan pengaruh yang positif dan signifikan terhadap hasil belajar dengan besar atau tingkat pengaruh yang berbeda-beda di setiap penelitian. Dalam penelitian dari Astri [16] minat belajar memberi pengaruh sebesar $25,8 \%$, minat baca memberi sumbangan pengaruh lebih besar dalam penelitian dari Ninu Septiani [17] yaitu 9,6\% sedangkan sumbangan pengaruh minat belajar terhadap hasil belajar di penelitian ini merupakan yang terbesar dengan koefisien determinasi sebesar 40,8\%. Perbandingan hasil penelitian ini dengan dua penelitian relevan sebelumnya 
tentu semakin memperkuat hasil pengujian hipotesis peneliti yang menghasilkan kesimpulan bahwa minat belajar siswa memang memberikan pengaruh positif dan signifikan terhadap hasil belajar matematika.

\section{SIMPULAN}

Berdasarkan hasil penelitian kausal yang telah melewati tahap pengolahan data, pengujian hipotesis, dan pembahasan hasil penelitian. Dapat ditarik simpulan bahwa terdapat pengaruh positif dan signifikan dari Minat Belajar Siswa terhadap Hasil Belajar Mata Pelajaran Matematika Kelas V SDN Kopo 01, Desa Kopo, Kecamatan Cisarua, Kabupaten Bogor.

Hal ini dapat dilihat dari hasil persamaan regresi $\hat{Y}=$ $-17,14+0,75 x$ yang berarti bahwa setiap kenaikan satu unit variable minat belajar akan menyebabkan peningkatan pada hasil belajar sebesar 0,75 unit. Kekuatan pengaruh dari minat belajar terhadap hasil belajar juga ditunjukkan dengan hasil perhitungan koefisien jalur sebesar 0,639 yang berkategori kuat. Selain itu minat belajar juga member kontribusi pengaruh terhadap hasil belajar sebesar 40,83\%. Ini menandakan kenaikan atau penurunan hasil belajar dipengaruhi oleh minat belajar sebesar $40,83 \%$, sedangkan sisanya sebesar $59,17 \%$ dipengaruhi oleh faktor lainnya.

\section{REFERENSI}

[1] OECD. 2015. Programme for International Student Assessment (PISA). Diakses dari http://www.oecd. org/pisa/PISA-2015-Indonesia.pdf pada tanggal 17 Juli 2019.

[2] Purwanto. 2011. Evaluasi Hasil Belajar. Yogyakarta : Pustaka Belajar

[3] Jihad, A. dan Haris, A. 2013. Evaluasi Pembelajaran. Yogyakarta: Multi Pressindo.

[4] Parwati, N.N. Suryawan, P.P. dan Apsari, R.A. 2018. Belajar dan Pembelajaran. Depok: Raja Grafindo.

[5] Y. Suchyadi and N. Karmila, The Application Of Assignment Learning Group Methods Through Micro Scale Practicum To Improve Elementary School Teacher Study Program College Students 'Skills And Interests In Following Science Study Courses," JHSS (Journal Humanit. Soc. Stud., vol. 03, no. 02, pp. 9598, 2019.

[6] Sudjana, Nana. 2009. Penilaian Hasil Proses Belajar Mengajar. Bandung: Remaja Rosda karya.

[7] Heruman. 2008. Model Pembelajaran Matematika di Sekolah Dasar. Bandung: Remaja Rosdakarya

[8] Slameto. 2015. Belajar dan Faktor-Faktor Yang Mempengaruhinya. Jakarta : Rineka Cipta.

[9] Djamarah, S.B. 2002. Psikologi Belajar. Jakarta: Rineka cipta.

[10] Susanto, Ahmad. 2014.Teori Belajar Pembelajaran Di Sekolah Dasar. Jakarta : Kencana Prenadamedia Grup.

[11] Jahja, Yudrik. 2010. Psikologi Perkembangan. Jakarta:Kencana.
[12] Taufani. 2008. Minat, Faktor-faktor yang mempengaruhi. Jakarta : Rineka cipta.

[13] Mashudi, Farid. 2018. Panduan Praktis Evaluasi Dan Supervisi Bimbingan Konseling. Yogyakarta: Diva Press.

[14] Supardi. 2016. Penelitian Autentik. Depok: PT. Raja grafindo Persada.

[15] Dimyati dan Mudjiono. 2015. Belajar dan Pembelajaran. Jakarta: Rineka Cipta

[16] Astri. 2015. Pengaruh Minat Belajar Terhadap Hasil Belajar Matematika Siswa Kelas IV SDN 1941 Sungai Abang Muara Tembesi. Jambi: FKIP Universitas Jambi.

[17] Septiani, Ninu. 2016. Pengaruh Minat dan Motivasi Belajar Terhadap Hasil Belajar Siswa Kelas V SDN Gugus Werkuduro Kecamatan Tegal Timur Kota Tegal. Semarang. Universitas Negeri Semarang. 